\title{
Euroscepticism and the Treaty of Lisbon: Why did the size of the No vote change so dramatically between the first and second referenda in I reland?
}

\author{
BENJ AMI N POWER ${ }^{1}$ \\ Australian National University \\ U4403960@anu.edu.au
}

\begin{abstract}
This paper demonstrates that the existing literature on voter preference formation in European referenda is insufficient to explain the shift in support for Lisbon in just 16 months. Building on a range of existing work to classify different Eurosceptic attitudes within Ireland, it focuses on why so many 'soft' Eurosceptics switched their votes from No to Yes between Lisbon I and II. Mainstream scholarly attention has converged around two distinct accounts of the way voters form preferences in European referenda, focusing on either domestic politics or the contents of individual treaties as the primary determinants of results. However, these explanations fail to describe for the significant role played by the worsening economic environment in Ireland between Lisbon referenda, as demonstrated by both polling data and immediate media reaction. This highlights a significant gap in the current understanding of European referenda, and points to an important future research agenda.
\end{abstract}

Key Words: European Union (EU), Euroscepticism, Ireland, Lisbon Treaty, Referenda, Preferences

The concept of Euroscepticism has become central to debate over the institutional structure of the European Union (EU), an issue which has caused heated and at times rancorous argument amongst European publics and policy-makers over the past decade of its history. Coming at the end of an extended period of debate begun with the Laeken Declaration of 2001, the Irish referenda over ratification of the Treaty of Lisbon in J uly 2008 and October 2009 provide a unique means of studying these competing beliefs and the key factors which underpin change in popular attitudes. In the only referenda to have been held on ratification in any EU memberstate, the Irish electorate initially rejected its adoption by a margin of $53.4 \%$ to $46.6 \%$. However, just 16 months later a second vote saw over two-thirds of voters supporting ratification, with a national rise in the Yes vote of approximately $20 \%$ and double-digit gains in all areas of the country. ${ }^{2}$ The dramatic extent of this turnaround raises important questions about the motivations of the Irish electorate in particular, as well as broader issues surrounding voter behaviour in European referenda across the continent. 3

\footnotetext{
${ }^{1}$ Benjamin Power graduated from the Australian National University in 2010 with a Bachelor of Philosophy (Honours) and a University Medal for Political Science. This paper is an edited version of the winning entry in the Honours category of the 2010 CESAA essay contest.

2Referendum Ireland, "Current Referendum", referendum.ie

$<$ http:// www.referendum.ie/referendum/ current/index.asp?ballotid=79 >,October 2009, accessed 10 October 2009; Noel Whelan, "Resounding Yes result reflects change in economic conditions", Irish Times <http:// www.irishtimes.com/ newspaper/ireland/2009/1005/1224255889586.html>, 5 October 2009, accessed 20 October 2009.

${ }^{3}$ In this paper, 'European referenda' will refer to national referenda over the ratification of EU treaties. It will employ the term 'referenda' as the plural of 'referendum,' rather than the more correct but less common 'referendums.' See Oxford English Dictionary, "Referendum," Oxford English
} 
This paper argues that the primary factor underpinning the changed preferences of so many Irish citizens between 2008 and 2009 was the troubled economic environment in Ireland during October 2009. Employing the concept of Euroscepticism to explore the nature of popular opposition to European integration, it first uses polling data and the results of past referenda to demonstrate the relatively low level of firm or hard' Euroscepticism in the Irish electorate as a whole. Subsequent investigation of why so many 'soft' Eurosceptics changed their votes from No to Yes in October 2009 reveals a gap in the existing literature on voter preference formation in European referenda, with its bifurcated emphasis on either domestic political affiliation or the specific contents of individual treaties. While both factors played a role in shaping voter preferences, this swing cannot be fully explained without reference to the broader economic situation in which Ireland found itself at the time of the second referendum. This conclusion reinforces the need for integration of broader concepts such as economic security into the literature on voter preferences in EU referenda, and points towards a new research agenda on the concept of Euroscepticism.

The most influential definition of Euroscepticism was put forward in 2000 by Szczerbiak and Taggart, who broke down anti-European sentiment amongst the continent's political parties into 'hard' and 'soft' categories. ${ }^{4}$ Hard Euroscepticism indicates a fundamental opposition to the principle of European integration, expressed through advocacy of complete separation from the EU or insistence on such stringent conditions for membership that participation becomes unfeasible. By contrast, soft Euroscepticism is not based upon rejection of European integration per se but instead comprises opposition to one or more specific policies being pursued at a European level. While this hard/ soft distinction is quite basic, it serves as the jumping-off point for most comparative analysis of Eurosceptic beliefs and has been adopted with minimal qualification by a number of other authors. ${ }^{5}$

This definition has been challenged by a group of authors who emphasise why individuals or parties adopt Eurosceptic attitudes, distinguishing different forms of Euroscepticism based on reasons for opposition to Europe rather than solely strength of conviction. For example, Tiersky breaks down anti-European sentiment into Euro-scepticism (complete rejection of European-level governance), Europessimism (doubts over the eventual success of integration), Euro-cynicism (suspicion of an eventual European super-state), and Euro-phobia (belief that the EU is inherently wasteful, anti-democratic and anti-national). ${ }^{6}$ In a similar vein, Sørensen reduces popular Euroscepticism to six categories based upon primary

Dictionary

$<$ http:// dictionary.oed.com.virtual.anu.edu.au/cgi/entry/50200737?single=1\&query type=word\&qu eryword=referendum\&first=1\&max to show=10 $>$, September 2009, accessed 7 November 2009.

${ }^{4}$ A. Szczerbiak and P. Taggart, 'Opposing Europe: Party Systems and Opposition to the Union, the Euro and Europeanisation,' Working Paper No. 36, Sussex European Institute, 2000. Although this study is focused on sentiment towards Euroscepticism at the individual rather than party level, definitions which are party-based but still applicable to individuals will be included in this review of Eurosceptic literature.

${ }^{5}$ See, for example, K. Henderson, 'Euroscepticism or Europhobia: Opposition Attitudes to the EU in the Slovak Republic,' Working Paper No. 50, Sussex European Institute, 2011 and C. Lees, 'Dark Matter': Institutional Constraints and the Failure of Party-Based Euroscepticism in Germany,' Political Studies Vol. 5, No. 2, 2002, pp. 244-67.

${ }^{6}$ R. Tiersky (ed.), Euro-skepticism: A Reader, Lanham, Rowman \& Littlefield, 2001. 
reason for mistrust of the EU. These range from poor political performance, a perceived threat to national sovereignty, and on to principled opposition to the European project as a whole. Harmsen has developed a single-axis scale to deconstruct the underlying reasons behind the attitudes of major political parties towards European integration, which range from simple criticism of individual EU policies through to single-issue anti-Europe parties such as the UKIP. Kopeck and Mudde propose a two-dimensional approach which classifies parties or individuals as Europhiles or Europhobes along one axis according to their broad 'support for the ideas of European integration,' while distinguishing between EU-optimists and EUpessimists based on their 'support for the European Union' along the other. ${ }^{7}$ These types of descriptive definitions highlight the particular outcomes that individual actors desire from the European project, offering a flexible alternative to simply measuring strength of sentiment.

However, the tight focus of this group of scholars on categorising objections to the European project as a whole weakens their ability to explain attitudes towards individual issues, as it does not leave room for the individuals or parties to deviate from a generally pro- or anti-European stance on one or more key subjects. For example, during negotiations over the introduction of a binding target for new-car $\mathrm{CO}_{2}$ emissions in 2007 and 2008, the broadly pro-European parties of the German governing coalition adopted a Eurosceptic approach to the Commission's proposed legislation on the basis that it was against their perceived national interests. ${ }^{8}$ As a result, these approaches have limited utility in the highly issue-specific area of European referenda.

Of more practical benefit is the sophisticated approach proposed by Flood and Usherwood, whose method allows a distinction to be drawn between general attitudes towards Europe and positions on individual issues. They present a six-point continuum which encompasses outright Rejectionism, more moderate but still sceptical Reformism and Minimalism, cautiously positive Gradualism, and finally committed Reformism and Maximalism. ${ }^{9}$ Using this system, a party may, for example, be described as Minimalist in terms of its attitude towards European integration in general, but Maximalist in its support for the development of Europewide legislation in one particular area. By enabling researchers to track attitudes towards individual policies as well as the EU itself, this definition provides a more nuanced understanding of Euroscepticism than the models provided by Tiersky, Sørensen and Harmsen.

\footnotetext{
${ }^{7}$ C. Sørensen, 'Danish and British Euroscepticism Compared: A Sceptical Assessment of the Concept,' Working Paper 2004/ 25, Danish Institute for International Studies, 2004; R. Harmsen, 'Euroscepticism,' in Y. Déloye (ed.), Dictionary of European Elections, Basingstoke, Palgrave, 2005; P. Kopeck and C. Mudde, The Two Sides of Euroscepticism: Party Positions on European Integration in East Central Europe,' European Union Politics Vol. 3, No. 3, 2002, pp. 299-304. See also M. Spiering, 'British Euroscepticism,' in R. Harmsen and M. Spiering (eds.), Euroscepticism: Party Politics, National Identity and European Integration, Amsterdam, New York, Rodopi, 2004, pp. 127-150. 8 For more background on this issue see EuAactiv, 'Merkel and Sarkozy 'breakthrough' on car emissions,' Euractiv.com <http:// www.euractiv.com/ en/transport/merkel-sarkozy-breakthrough-caremissions/article-173199 >, $10 \mathrm{~J}$ une 2008, accessed 14 August 2009; S. Mulvey, 'EU car CO2 fight only beginning,' BBC News <http:// news.bbc.co.uk/2/hi/ europe/6337057.stm>, 7 February 2007, accessed 14 August 2009.

${ }^{9}$ C. Flood and S. Usherwood, Positions, Dispositions, Transitions: A Model of Group Alignment on EU Integration,' Paper presented at the 55th Annual Conference of the Political Studies Association, Leeds (5-7 April 2005).
} 
In order to balance between convenience and accuracy in analysing the Irish referenda on Lisbon, this paper will employ a combination of Flood and Usherwood's work and the hard/soft definition of Szczerbiak and Taggart. To this end Rejectionism, Reformism and Minimalism will be grouped together as broadly hard' Euroscepticism, while Gradualists and Reformists who voted against ratification of Lisbon will be described as 'soft' Eurosceptics.

The Irish electorate is characterised by a high level of support for the EU, with little hard Euroscepticism in the form of Rejectionist, Revisionist or Minimalist sentiment. This is reflected in the successful ratification of all five European treaties put to the electorate in referenda since 1987, albeit with the need for secondary votes in the case of the Nice and Lisbon Treaties. ${ }^{10}$ Despite the No result, surveys in the wake of the first Lisbon referendum showed a high level of support for the EU itself.

Eurobarometer's post-polling results found that only 5\% of No voters rejected Lisbon due to mistrust of a unified Europe, while just $8 \%$ of participants in a simultaneous Milward Brown IMS survey felt EU membership was a bad thing. ${ }^{11}$ Given such low support for complete withdrawal from the EU, less than $10 \%$ of the Irish electorate can be categorised as Rejectionist Eurosceptics.

This basic indication of sentiment towards Europe can be refined through an analysis of Ireland's voting history in EU referenda since its accession in 1972, in which at least $30 \%$ of voters have rejected each proposal. Given the range of issues at stake across these five primary treaties, this indicates that approximately one-third of Ireland's population are hard Eurosceptics who will not support any European treaties seen to strengthen the influence of the EU. ${ }^{12}$ In turn, this provides strong evidence that approximately $20 \%$ of the electorate are Minimalist or Revisionist Eurosceptics, their desire not to increase the power of the EU guaranteeing a No vote despite not desiring withdrawal from the EU altogether.

However, although these results evidence the limited extent of hard Euroscepticism in Ireland, they reveal little about why so many soft Eurosceptics from 2008 were eventually persuaded to vote for the Treaty 16 months later. In order to fully understand the driving factor behind this conversion, it is necessary to investigate

\footnotetext{
${ }^{10}$ D. Hierlemann, 'Ireland's second attempt,' Spotlight $<$ http:// aei.pitt.edu/ 11578/01/spotlight_europe - Ireland's_Second_Attempt.pdf $>$, September 2009, accessed 7 October 20092

${ }^{11}$ Eurobarometer, "Post-referendum survey in Ireland: Analytical Report," Eurobarometer $<$ http:// ec.europa.eu/public opinion/flash/fl 245 full en.pdf $>$, J uly 2008, accessed 2 October 2009 pp. 22, 24; M. Brown IMS, 'Post Lisbon Treaty Referendum Research Findings September 2008,' Irish Department of Foreign Affairs <http:// www.dfa.ie/ uploads/ documents/Publications/ Post\%20Lisbon\%20Treaty\%20Referendum\%2 0Research\%20Findings/ post\%20lisbon\%20treaty\%20referendum\%20research\%20findings sept08. pdf $>$, September 2008, accessed 2 October 20093 . The Milward Brown IMS report found that $18 \%$ of the electorate believed Ireland should dilute its involvement with the EU, but that only $8 \%$ thought EU membership was a bad thing entirely (ibid., $3 \& 19-20$ ). Sinnott et al find that $13 \%$ of No voters thought Lisbon was a bad idea in general, whereas $18 \%$ focused specifically on the loss of sovereignty/ independence as a result of the Treaty. While this combination of figures is slightly different to those found by Eurobarometer and Milward Brown IMS, the overall figure of $31 \%$ lends support to the theory that about one-third of the Irish population are hard' Eurosceptics (Richard Sinnott et al, "Attitudes and Behaviour in the Referendum on the Treaty of Lisbon," Foreign Affairs $<$ http:// www.foreignaffairs.gov.ie/ uploads/documents/ucd\%20 geary\%20institute\%20 report).pdf>, 6 March 2009, accessed 2 October 2009. ${ }^{12}$ D. de Brédún, 'Economic adversity a key player for Yes campaign,' Irish Times $<$ http:// www.irishtimes.com/ newspaper/ ireland/2009/1005/ 1224255888477.html > 5 October 2009, accessed 20 October 2009; see also Hierlemann, op. cit., pp. 3-4.
} 
what factors most affect the preferences of swinging voters who are neither hard Eurosceptics nor ardent Europeanists in EU referenda.

Studies of voter behaviour in European referenda draw upon a broader body of research on referenda in general, which has produced a large volume of comparative literature. ${ }^{13}$ However, comparative studies of European referenda are considerably rarer, in large measure due to the relatively small number of referenda to provide data for analysis. Those comparative studies which do exist can be divided into three distinct categories. Scholars such as Svensson argue that the outcomes of European referenda are primarily determined by the attitudes of voters towards the particular Treaty in question, and that issues rise above partisan political orientation in shaping voter preferences. Through analysis of the five EU referenda in Denmark between 1972 and 1998, Svensson concludes that European polls 'reflect more than the popularity of the government ... the beliefs, opinions and attitudes of voters did play a role in explaining their behaviour.' ${ }^{\prime 14}$

A slight modification of this approach is proposed by Gabel, who argues that voters determine their personal attitudes towards individual European referenda through a rational cost/ benefit analysis of their own economic interests. The issues which most affect these beliefs, opinions and attitudes can vary widely between different countries, meaning that different factors are likely to take centre stage in each individual referendum. ${ }^{15}$ Svensson and Gabel's strategy is consequently closely entwined with the broader research agenda of Euroscepticism, with a shared focus on explaining the nature of voters' views towards Europe and the source of these opinions. This 'issue-based' theory of vote formation is therefore a very fluid approach, without a universally applicable formula for assessing the key factors in referenda outcomes.

A different strategy is adopted by scholars who argue that European referenda are not really about European issues at all, but instead reflect the domestic political views of the electorate. This view draws upon the concept of 'second-order elections,' first developed by Reif and Schmitt to describe elections to the European parliament. They argue that "European" elections are simultaneous national elections in each of the EC-member nations,' and that 'many voters cast their votes in these elections ... on the basis of factors in the main political arena of the nation.' 16 Scholars such as Franklin have adopted the concept of second-order elections to explain voting patterns in European referenda, arguing that individuals base their vote primarily on domestic political considerations rather than the issue titularly at hand. Specific

\footnotetext{
${ }^{13}$ For a summary, see L. LeDuc, 'Opinion change and voting behaviour in referendums,' European J ournal of Political Research Vol. 41, 2002, pp. 711- 732. One of the key conclusions of this research is that voter choice in referendums is frequently not rational or objective. In limiting its focus to explaining only the reasons why voters swapped from No to Yes votes, this paper bypasses this problem by focusing only on the reasons for this swap rather than whether they were rational or not. ${ }^{14} \mathrm{P}$. Svensson, 'Five Danish referendums on the European Community and European Union: A critical assessment of the Franklin thesis,' European J ournal of Political Research Vol. 41, 2002, pp. 733- 750.

${ }^{15}$ See M. Gabel, 'Public Support for European Integration: An Empirical Test of Five Theories,' J ournal of Politics Vol. 60, No. 2, 1998, pp. 333- 54; Svensson, op. cit.; A. Szczerbiak and P. Taggart, The Politics of European Referendum Outcomes and Turnout: Two Models, West European Politics Vol. 27, No. 4, September 2004, pp. 557 - 583, p. 564.

${ }^{16} \mathrm{~K}$. Reif and H. Schmitt, 'Nine second-order national elections - a conceptual framework for the analysis of European election results,' European J ournal of Political Research Vol. 8, No. 1, 1980, pp. 8-9.
} 
motivation for voting behaviour varies between different cases, with loyalty towards a particular political party most influential in some situations and satisfaction with the current government dominant in others. ${ }^{17}$ However, regardless of these variations, Franklin et al argue that 'partisan attachments are almost certainly the primary factor in referendum voting.' 18

In 2002 Franklin introduced a substantial revision of his original argument, which attempted to synthesise this approach with that of Svensson et al. This revised approach centres on a distinction between referenda of high and low importance to voters. In his latter guise Franklin argued that referenda put to a largely disengaged population would be fought primarily on domestic terms, while in referenda of higher salience to voters 'the standing of the government can still influence the outcome of a referendum whose result would otherwise have been close.' 19 With turnout of above $50 \%$ and a winning margin of only $6.8 \%$, the first Irish referenda on Lisbon would certainly appear to fall into this latter category. Franklin and other advocates of the primacy of domestic politics maintain that partisan preferences play a key role in determining the outcome of referenda, and only become a secondary factor when an issue of even greater salience arises in a passionate and closelycontested referendum.

The third major school of thought is exemplified in the work of Hobolt, who argues that voter behaviour is shaped by the information which they absorb during the campaign rather than a single independent variable. This information may take the form of partisan cues from political parties relating primarily to domestic politics, or alternatively comprise more general knowledge of European integration and the consequences of the proposed treaty. Attitudes towards a specific referendum are shaped by the relative weight which is placed on each of these in any given campaign, leading to a dynamic relationship between the different factors which affect voter behaviour. ${ }^{20}$

However, the utility of Hobolt's approach is limited by its failure to distinguish between general attitudes towards Europe and opinion of specific treaties. For example, a broadly Reformist individual may oppose a complex treaty such as Lisbon due to just one of its major components, such as the inclusion of the Charter of Fundamental Rights. This flaw is addressed by Sczerbiak and Taggart, who hold that voter preferences are informed both by their attitudes towards the particular integration measure being proposed as well as the direction, strength and clarity of elite cues. ${ }^{21}$ Such a model recognises that preferences can be determined by general

\footnotetext{
${ }^{17}$ M Franklin et. al, 'Attitudes to Europe and Referendum votes: A response to Siune and Svensson,' Electoral Studies Vol. 13, No. 2, 1994, pp. 117- 121; M. Franklin et al, ,Uncorking the Bottle: Popular Opposition to European Unification in the Wake of Maastricht,' J ournal of Common Market Studies Vol. 32, No. 4, 2002, pp. 455- 72.

${ }^{18}$ See Szczerbiak and Taggart, 'The Politics of European Referendum Outcomes and Turnout,' op. cit., p. 564.

${ }_{19}$ M.Franklin, Learning from the Danish case: A comment on Palle Svensson's critique of the Franklin thesis,' European J ournal of Political Research Vol. 41, 2002, pp. 751- 757.

${ }^{20}$ Sara Hobolt, Europe in Question: Referendums of European Integration, Oxford, Oxford University Press, 2009.

${ }^{21}$ Szczerbiak and Taggart, 'The Politics of European Referendum Outcomes and Turnout,' op. cit.; A. Szczerbiak and P. Taggart, 'Conclusion: Towards a Model of (European) Referendums,' West European Politics Vol.27, No. 4, September 2004, pp. 749 - 777. In this latter work, Szczerbiak and Taggart analyse only the 2003 referenda on EU accession in Eastern European nations. As a result,
} 
attitudes towards Europe, partisan political positions, as well as opinions on a specific treaty, in a similar manner to the comprehensive definition of Euroscepticism put forward by Flood and Usherwood. Nevertheless, as recognised by Sczerbiak and Taggart themselves, the predictive capabilities of this model are restricted by its inability to indicate which of these influences will have the greatest effect on the outcome of any given referendum. In order to determine the ability of these models to explain voter preference formation, it is to an investigation of the most important factors in the Irish referenda on Lisbon that this paper now turns. The broad, cross-party increase in support for the Lisbon Treaty between the first and second referenda strongly suggests that the changed outcome was not a result of partisan political affiliation. ${ }^{22}$ Lisbon I attracted support from the governing Fianna Fáil party, opposition Fine Gael and smaller groups such as Labour and the Greens, with only Sinn Féin advocating its rejection. At this first vote 95\% of Sinn Féin supporters followed the party line by voting No, while between $40 \%$ and $60 \%$ of those affiliated with pro-Lisbon parties voted against the Treaty. ${ }^{23}$ However, this trend was reversed in Lisbon II, when more followers of pro-Lisbon parties voted Yes and only two-thirds of Sinn Féin supporters committed to voting No. ${ }^{24}$ Although there was undoubtedly a strong correlation between support for Sinn Féin and a No vote in both referenda, the increase in Yes sentiment amongst party supporters before the second vote indicates that many soft Eurosceptics were willing to change their voting preferences despite a consistent No message from the party. Many of those who did not are likely to have been hard Eurosceptics anyway, standing against the expansion of powers for the EU in almost any circumstances. Indeed, Sinn Fein has opposed every European referenda in Ireland since 1972. ${ }^{25}$ As a result, it is very difficult to say that allegiance to Sinn Féin caused many more people to vote No than they would have otherwise, or that it was a sudden renewal of partisan loyalty which induced such a large portion of the electorate to change their minds between Lisbon I and II.

Further evidence that the 2009 referendum was not determined by the domestic political preferences of the Irish electorate comes from the fact that it did not degenerate into a 'second-order' national election based on domestic politics. Opponents of the Treaty worked to portray the referenda as a proxy vote on the leadership of Taoiseach Brian Cowen and Fianna Fáil, displaying posters claiming 'the only job Lisbon saves is Cowen's' and attempting to associate the economic

their survey uses the criteria of 'general levels of support for EU membership.' Their suggested revision to 'attitudes towards the particular issue at hand' is contained on page 772 of Szczerbiak and Taggart, Ibid.

22 The EU has provided its own summary of the contents Lisbon Treaty at European Union, "The Treaty of Lisbon: Taking Europe into the 21st century", Europa.eu $<$ http:// europa.eu/lisbon treaty/index en.htm>, 23 October 2009, accessed 30 October 2009. An independent summary is provided by Eüractiv, "The Treaty of Lisbon'”, euractiv.com $<$ http:// www.euractiv.com/ en/ future-eu/treaty-lisbon/article-163412>, 21 September 2009, accessed 30 October 2009.

23 Eurobarometer, op. cit., p. 17.

24 S. Collins, 'Relief for Yes side but opponents can take heart too,' Irish Times $<$ http:// www.irishtimes.com/ newspaper/ireland/ 2009/0925/ 1224255209220.html>, 25 September 2009, accessed 20 October 2009.

25 S. Collins, 'Recession focused minds on how vital EU is to our fortunes,' Irish Times $<$ http:// www.irishtimes.com/ newspaper/ opinion/ 2009/ 1005/ 1224255886295.html>, 5 October 2009, accessed 20 October 2009. 
policies of the Lisbon Treaty with those that caused the economic crisis. ${ }^{26}$ However, despite these attempts to whip up a protest vote against the unpopular incumbent government, the decisive endorsement of Lisbon in the second referenda demonstrated the ability of the electorate to rise above these domestic political considerations. Opposition parties such as Fine Gael and the Greens chose not turn the referendum into a proxy vote on the performance of Cowen's government, instead advocating acceptance of the Treaty on the basis that it was in their perceived national interest. ${ }^{27}$ For example, although opposition leader Enda Kenny recognised that 'Brussels has propped up our economy,' he did not use this to attack the government during the referendum campaign but rather advocate support of the Treaty. ${ }^{28}$ Given the drop in popularity of Fianna Fáil from $42 \%$ in the 2007 general election to less than $25 \%$ by September 2009, the result of the second referendum demonstrated the ability of voters to distinguish between an unpopular Government and the issue of the treaty. ${ }^{29}$

While opposition to the government or support of Fianna Fáil may have played a role in shaping the preferences of some Irish voters, the decisive swing towards the Yes camp without a corresponding change in the attitudes of major political parties suggests that these were primarily 'hard' Yes or No voters who would not have changed their position on Lisbon even if elite cues were different. Particularly in light of Franklin's revised thesis of 2002, it is evident that the high political salience of the Lisbon debate in Ireland ensured domestic political preferences were not the decisive factor in either Lisbon I or II. Other, more significant factors must have played a greater role in shaping the outcome of the Irish referenda.

The search for these factors begins with the other key theme in the debate over the formation of voter preferences; attitudes towards the content of the Treaty itself. According to the theses of scholars such as Svensson, the most important factor in explaining the swing from No to Yes votes between Lisbon I and II must have been growth in approval of its most controversial provisions. These key features can be identified through post-polling survey data from the 2008 referendum.

Eurobarometer found that $12 \%$ of No votes were motivated by a desire to protect Irish identity, with fears about the loss of Ireland's neutrality, the consequences of not having a commissioner, and abolition of control over the tax system being cited

${ }^{26}$ M. Simpson, 'J ob woes colour Irish treaty vote,' BBC News $<$ http:// news.bbc.co.uk/ 2/ hi/ europe/ 8285473.stm>, 2 October 2009, accessed 21 October 2000; Sinn Féin, "Alternative Guide to Lisbon 2", Sinn Féin <http:// www.sinnfein.ie/ contents/ 17382>, September 2009, accessed 24 October 2009; D. Finnan, 'Lisbon debate turns sour before referendum,' Radio France Internationale $<$ http:// www.rfi.fr/anglais/actu/articles/117/article_5287.asp> 30 September 2009, accessed 21 October 2009.

${ }^{27} \mathrm{~J}$. Dymond, 'New Irish test looms for Lisbon,' BBC News <http:// news.bbc.co.uk/ 2/ hi/ europe/ 8256356.stm>, 15 September 2009, accessed 21 October 2009. 28 D. Finnan, 'Recession likely to decide Irish referendum,' Radio France Internationale $<$ http:// www.rfi.fr/anglais/actu/articles/ 118/article 5317.asp>, 2 October 2009, accessed 21 October 2009; Collins, 'Recession focused minds on how vital EU is to our fortunes;' M. Lord, 'Downbeat finale for Fianna Fáil and the frontman no one wants to see,' Irish Times $<$ http:// www.irishtimes.com/newspaper/ireland/2009/1001/1224255612373.html >, 1 October 2009, accessed 20 October 2009.

${ }^{29}$ de Brédún, op. cit.; Red C Research, “Voting Intention Opinion Poll, 27 September 2009”, Red C Research <http:// www.redcresearch.ie/ documents/SBP27thSeptElectionandLisbonPollReport.pdf>, 27 September 2009, accessed 24 October 2009 pp. 6-8. 
by $6 \%$ of respondents each. The results of Milward Brown IMS (MBI) broadly mirror these findings, while Sinnott et al find a slightly higher figure expressing concerns over neutrality with less focus on the commissioner and taxation issues. ${ }^{30}$ In addition to these specific concerns about the consequences of ratifying Lisbon, a major cause of the No vote in 2008 was a more general lack of understanding about the contents of the Treaty. The No campaign placed a great deal of emphasis on encouraging those confused about the Treaty to vote against it, with heavy use of the slogan 'If in doubt, vote No.' Eurobarometer concluded that the most often-cited reason for voting No was a lack of information about the Treaty, while MBI found that $42 \%$ of No voters identified a knowledge deficit as the primary factor contributing to their decision. The latter survey concluded that 'Across all focus groups the level of understanding of the Lisbon Treaty is best described as fairly poor, but was probably most pronounced and most likely to explain voter behaviour among Soft No voters.' 31 Without being certain of its consequences Irish voters were understandably reluctant to vote in favour of Lisbon, and '[a] lack of information was the reason why the majority of the non-voters did not go to the polls and the most commonly given reason for voting no.'32

Attempting to attract those soft Eurosceptics who initially voted against Lisbon based on fear about its effects, the Yes campaign made a deliberate attempt to allay both specific and general concerns amongst the Irish public. EU member-states provided a guarantee that Lisbon would not threaten the key interests identified in the wake of Lisbon I, reinforcing Ireland's right to decide its own stance on abortion, tax rate and foreign policy. In addition, the European Council agreed to maintain the existing system of one commissioner for each member-state. ${ }^{33}$ These guarantees provided greater certainty to the Irish electorate that their concerns had been both heard and accepted. On top of these concrete changes, supporters of the Treaty such as Taoiseach Cowen and Ryanair Chief Executive Michael O'Leary worked to enhance popular knowledge of the Treaty, assisted by the autonomous Referendum Commission. ${ }^{34}$ This two-pronged strategy of allaying specific concerns as well as

\footnotetext{
30 Eurobarometer, op. cit., p. 19; M. Brown IMS, op. cit., p. 12; Sinnott et al, op. cit., p. 14.

31 Eurobarometer, op. cit., pp.18-20; Sinnott et al, op. cit., pp.13-14. During both Lisbon referenda the main players in the No campaign were Sinn Fein, the non-profit organisation Coir, and independent activists such as businessman and Libertas founder Declan Ganley.

32 U. Schneider, The Treaty of Lisbon: Reasons for the Irish No Vote, Munich, Ravensburg; GRIN Verlag, 2009, p. 7; M. Brown IMS, op. cit., pp. 7 and 12. The Milward Brown IMS survey also concludes that lack of knowledge was the deciding issue in the campaign' (Ibid, p. 12).

33 European Council, 'Decision of the Heads of State or Government of the 27 Member States of the EU, Meeting Within the European Council, on the Concerns of the Irish People on the Treaty of Lisbon,' Irish Department of Foreign Affairs <http:// www.dfa.ie/ home/ index.aspx?id=34239>, 11 December 2008, accessed 14 October 2009. While the legal status of the country-specific guarantees given to Ireland are somewhat unclear until they are added to a further EU treaty. The guarantee to maintain one commissioner per country, however, is only a verbal commitment by EU member-states and can be changed at any point by unanimous agreement. See Euractiv, 'EU summit gives in to Irish demands on Lisbon Treaty,' Euractiv.com <http:// www.euractiv.com/ en/ future-eu/ eu-summit-givesirish-demands-lisbon-treaty/article-178004>, 12 December 2008, accessed 8 November 2009. 34 de Brédún, op. cit.; T. Barber, 'From No to Yes: Switch Voters Hold Key to Ireland's EU Poll,' Financial Times $<$ http:// blogs.ft.com/ brusselsblog/2009/ 10/ from-no-to-yes-switch-voters-hold-keyto-irelands-eu-poll/ > 2 October 2009, accessed 14 October 2009; D. Finnan, 'Why are the Irish voting on the Lisbon treaty again?,' Radio France Internationale $<$ http:// www.rfi.fr/anglais/actu/articles/117/article 5262.asp>, 29 September 2009, accessed 21 October 2009. According to the survey by Milward Brown IMS, those who voted No in 2008 were far less likely to have received their information about Lisbon from independent sources than those voting Yes. The role of impartial sources such as the Referendum Commission was consequently of
} 
reducing general wariness was designed to increase the knowledge of voters about the consequences of ratification, and consequently increase their comfort with the Treaty itself.

The success of this push to increase public understanding of the Treaty can be seen in both the polling data and turnout figures from each referendum. Two weeks before the second vote $63 \%$ of Irish citizens felt they had some understanding of the Treaty, as compared to only $44 \%$ in 2008 . J ust $19 \%$ of the electorate remained undecided as to whether to vote for or against the Treaty a week out from the second Lisbon referendum, while at an equivalent stage of the first vote $35 \%$ professed indecision. And the increase in turnout of 201,000 people in 2009 indicates a greater level of engagement with the Treaty than was the case 16 months earlier, providing a strong indication that knowledge of the contents and consequences of the Treaty was enhanced between referenda. ${ }^{35}$ The effect of this greater understanding on voting behaviour was shown by a number of informal surveys conducted in the lead-up to the second poll. For example, an Irish Times doorknock of 250 homes one week before the poll found the most significant factor driving in prompting a switch from No to Yes was a greater understanding of the issues at hand, while surveys conducted for the BBC found similar evidence that voters 'seem to have become more educated on Lisbon this time and realise it will not affect abortion, taxation, neutrality and the commissioner issue.' 36 Both polling data and turnout figures indicate that the Irish electorate showed a markedly enhanced understanding of the contents of the Lisbon Treaty in 2009, an increase which appears to be strongly linked to the dramatic rise in support for the Yes campaign by informal survey data. As a result, Svensson's proposition that perception of the Treaty itself would be far more important than domestic political preference in shaping voter behaviour appears to be borne out.

great importance. See Milward Brown IMS, op. cit., pp. 9-10; Finnan, 'Lisbon debate turns sour before referendum,' op. cit.; D. Finnan, 'Yes voters optimistic on Lisbon Treaty,' Radio France Internationale

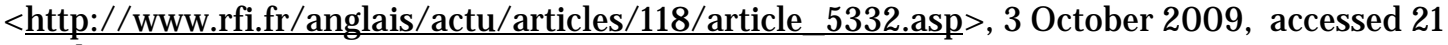
October 2009.

35 Finfacts, "Lisbon Treaty: Irish Referendum Commission confirms high public understanding of the key elements of Treaty", Finfacts.ie

<http:// www.finfacts.ie/irishfinancenews/ article_1017934.shtml >, 21 September 2009, accessed 14 October 2009; Collins, 'Relief for Yes side but opponents can take heart too,' op. cit.; Referendum Ireland, op. cit.; Noel Whelan, 'Resounding Yes result reflects change in economic conditions,' Irish Times <http:// www.irishtimes.com/ newspaper/ireland/2009/1005/1224255889586.html>, 5 October 2009, accessed 20 October 2009. The EU's Eurobarometer survey in the wake of the 2008 referendum found that $55 \%$ of the electorate had made up their minds how to vote on the Treaty in the last three weeks of the campaign, were more likely to commit to the No than Yes camp. See

Eurobarometer, op.cit., 14. See also the similar conclusions of Milward Brown IMS, op. cit., p. 6. Red C data analysis of both the 2008 and 2009 referenda clearly demonstrates the smaller number of vacillating voters late in the second campaign compared to the first as well as the way these broke primarily for the No position in 2008. See Red C Research, Voting Intention Opinion Poll, 8 J une 2008,' Red C Research <www.redcresearch.ie/documents/SBP8thJ unePollReport.pdf>, 8 J une 2008, accessed 24 October 2009.

36 BBC News, "Lisbon Treaty vote: Irish voices", BBC

<http:// news.bbc.co.uk/2/ hi/ europe/ 8272802.stm>, 29 September 2009, accessed 29 October 2009; Harry McGee, 'Evidence on the doorsteps suggests slight swing to Yes,' Irish Times $<$ http:// www.irishtimes.com/ newspaper/ireland/ 2009/ 1001/ 1224255613292.html>, 1 October 2009, accessed 20 October 2009.; M. Fitzgerald, "Second time around: how Dublin South-West voters are seeing it this time", Irish Times

$<$ http:// www.irishtimes.com/ newspaper/ireland/ 2009/0928/1224255368185.html>, 28 September 2009, accessed 20 October 2009. 
However, while the large swing between 2008 and 2009 can be strongly linked to a greater understanding of the Treaty, it does not prove that this enhanced level of knowledge was the only or even the primary factor behind the final result. Further analysis of both popular and media opinion from the 2009 referendum indicates that the fundamental reason so many citizens swapped No for Yes votes was not partisan affiliation nor the specific contents of the Lisbon Treaty, but a recognition that Ireland's parlous economic situation necessitated the maintenance or even strengthening of close ties to the EU.

In 2008, less than half of Yes voters and only $17 \%$ of No voters felt the rejection of Lisbon would adversely affect the economy. However, the global economic crisis hit particularly hard in Ireland, with unemployment rising to nearly $13 \%$ and the budget deficit blowing out by almost $11 \%$ between the first and second referenda. ${ }^{37}$ This economic downturn had a significant effect on perceptions of the consequences of rejecting the Lisbon Treaty. These changed opinions were evident in the informal surveys carried out by the Irish Times and Wall Street J ournal in the pre-election period, which found many Irish felt obliged to support the treaty 'under protest.'38 Similarly, polling by Radio France Internationale and the BBC revealed a recognition that the economy would be the key determinant of the referendum's result, regardless of whether they supported ratification or not. 39 This data strongly suggests that economic concerns played at least as high a role as changed perceptions of Lisbon's contents in driving the 2009 upturn in the Yes vote.

This conclusion was also drawn by a majority of media analysts covering the Irish referendum, who saw the eventual success of the referendum as primarily due to popular fear of negative economic consequences should Lisbon be rejected. Two weeks before the poll Hewitt from the BBC observed that the key argument was likely to be economic recovery, while the Irish Times' Whelan concluded immediately after it that '[t]his swing was all about the changed economic context ... [the Irish] have now out of economic desperation decided this time they had no option but to vote Yes.' 40 Der Spiegel held that 'the recession was plainly the deciding factor in the sharp turnaround,' a sentiment echoed by the Economist and Financial Times. ${ }^{41}$ And Dutch newspaper de Volkskrant argued that The financial crisis has taught the "Celtic Tiger" that it is safer to be in the EU harbour during a storm.' ${ }^{2}$ This sample

37 Eurobarometer, op. cit., p. 26; Shane Harrison, 'Close treaty poll result forecast,' BBC News $<$ http:// news.bbc.co.uk/2/hi/europe/ 8281602.stm>, 30 September 2009, accessed 21 October 2009. See also Milward Brown IMS, op. cit., 22; Simpson, op. cit.

38 McGee, op. cit.; see also Mary Fitzgerald, 'Arguments linking treaty with jobs gain traction in Tallaght,' Irish Times

$<$ http:// www.irishtimes.com/newspaper/ireland/2009/0928/1224255368102.html>, 28 September 2009, accessed 20 October 2009.

39 Finnan, 'Yes voters optimistic on Lisbon Treaty,' op. cit.; BBC News, op. cit.; Simpson, op. cit.; Cathy Grieve, 'EU treaty stirs Irish grassroots,' BBC News < http:// news.bbc.co.uk/2/hi/europe/ 8273712.stm>, 26 September 2009, accessed 21 October 2009. 40 Whelan, op. cit.

${ }^{41}$ Economist, 'The future's Lisbon,' The Economist 10-16 October 2006, pp. 23-25; Siobhán Dowling, Trish Lisbon Vote IS 'A Cry For Help,' Spiegel Online $<$ http:// www.spiegel.de/ international/ europe/ 0,1518,653282,00.html >, 5 October 2009, accessed 21 October 2009.

42 Deutsche Welle, 'Press review: Ireland and the Lisbon Treaty,' DW-World.de <http:// www.dwworld.de/ dw/ article/ $0,4758321,00 . \mathrm{html}>, 5$ October 2009, accessed 20 October 2009. On global reaction to the referendum result see Kathy Sheridan, 'World's media circus moves on having come to Ireland's big top to hear the lion roar No,' Irish Times 
reflects a broad consensus amongst the European media that the key determining factor in the second Lisbon vote was fear over the economy. Despite the lack of formal opinion surveys or academic analysis of the second Irish referendum, the shared opinion of so many prominent media outlets provides a strong indication that changed economic circumstances played a highly significant role in explaining the large swing in voting behaviour between Lisbon I and II.

The changed results of the Irish referenda on Lisbon cannot be explained by the theoretical approaches of either Franklin (1994 or 2002) or Svensson, as neither domestic politics nor the specific contents of the Treaty were the key factor underpinning voter preferences. The flexibility of Szczerbiak and Taggart's methodology provides it with greater explanatory power, as it incorporates the effect of general attitudes towards Europe into its analysis. ${ }^{43}$ However, the central role which Ireland's broader economic context played in the result of Lisbon II points to a gap even in this analysis of the way citizens vote in European referenda. In the Irish case, the need to maintain close links to the EU in difficult economic times did not necessarily change voters' perception of the particular effects of the Treaty or view of their domestic politicians. Nevertheless, it did alter the perceived importance of being close to Europe, and consequently had a significant effect upon the outcome. ${ }^{44}$ Such external concerns could conceivably play a similar role in other European referenda. For example, a major terrorist attack or military confrontation immediately before a referendum could push security concerns to the forefront of the electorate's attention, dramatically reducing the role of partisan affiliation or Treaty minutiae in determining its outcome. More work needs to be done on exploring what type of issues can have this transformative effect on European referenda, and investigating how they can be integrated into existing models of voter preference formation.

Euroscepticism can be best understood as a combination of opinions towards European integration in general as well as attitudes towards a specific issue or treaty. Consequently, the most analytically useful definition of Euroscepticism is Flood and Usherwood's six-point continuum. This model is therefore applied here to classify the different Eurosceptic attitudes within Ireland, and identify the beliefs of those voters who switched from No to Yes between 2008 and 2009. While the existing literature on preference formation is divided over whether domestic political

$<$ http:// www.irishtimes.com/newspaper/ireland/ 2009/1005/1224255888493.html >, 5 October 2005, accessed 20 October 2009.

43 Szczerbiak and Taggart also differ from Franklin and Svensson by focusing not just on political figures but also a broader definition of 'elites,' including non-party actors such as heads of state and religious organisations. The Irish example demonstrates the important role which these elites had in reducing the knowledge deficit amongst the electorate about the contents of the Treaty, lending further explanatory power to their approach.

${ }^{44}$ Brian Coll, 'The E.U.'s Future: Back in the Hands of Irish Voters,', Time $<$ http:// www.time.com/time/ world/article/ 0,8599,1926522,00.html\#ixzzOW4rztiAY>, 29 September 2009, accessed 29 September 2009; Anne J olis, 'How the EU Got the Irish to 'Yes.', Wall Street J ournal <http:// online.wsj.com/article/ SB10001424052748704471504574451720408422980.html>(4 October 2009) accessed 20 October 2009. Milward Brown IMS argue that the economy also played a significant role in ensuring the initial rejection of the Lisbon Treaty in 2008, with the onset of economic downturn leading to an increase in protectionist sentiment that only transformed into support for closer ties with Europe and Treaty ratification once the scale of the crisis became evident. This also appears to lend support to the proposition that external concerns such as the economy do play a key role in a broad range of referenda. Milward Brown IMS, op. cit., pp. 12-3. 
affiliation or the specific contents of a particular treaty are more important in shaping preference formation in European referenda, the Irish example highlights the important role of broader economic and security contexts in shaping voter choice. These external factors need to be incorporated into a more integrated model of vote formulation, so that all three factors are recognised as contributing to the adoption of a soft Eurosceptic position. The logical place to start such a synthesis is with the pre-existing work of Szczerbiak and Taggart.

More detailed research is also needed to fully understand the results of the 2009 Lisbon referendum. For example, the role of the press in influencing public opinion has been little analysed to date, while widespread resentment at the government's decision to hold a second referendum despite its initial defeat played a significant but ill-understood role in encouraging No voters. Particular quirks of the Irish electorate may also give deceptive results which are not broadly applicable to the EU as a whole. ${ }^{45}$ Such research into the causes of the swing from No to Yes votes in 2009 would serve to supplement and refine the preliminary conclusions drawn here.

${ }^{45}$ For example, R. Sinnott argued in 2003 that of the 23 referenda held up to that point only four entailed major conflict between political parties, despite at least 16 relating to underlying cleavages within society on which there were substantial divisions amongst the population. This points to a long-standing tendency of Irish political parties to adopt the same position on issues raised in referenda, even if such a stance does not reflect the variety of views at a non-elite level. The explanation for this anomaly may be the historical division of Irish parties and citizens along religious rather than political or class-based lines. See R. Sinnott, 'Attitudes and behaviour of the Irish electorate in the second referendum on the Treaty of Nice: Results of a survey of public opinion carried out for the European Commission Representation in Ireland,' Working Paper, University College Dublin <http:// www.ucd.ie/dempart/ workingpapers/nice2.pdf>>, 26 February 2003, accessed 10 September 2009; Michael Holmes (ed.), Ireland and the European Union: Nice, enlargement and the future of Europe, Manchester, Manchester University Press, 2005. 